\title{
PRZESILENIA KANCLERSKIE W CESARSTWIE NIEMIECKIM W 1917 R. NA ŁAMACH KRAKOWSKIEGO „GLOSU NARODU”
}

Artykuł ten opisuje przesilenia roku I9I7 związane ze zmianami na urzędzie kanclerza Rzeszy pomiędzy lipcem a listopadem. Ujęcie tego zagadnienia było możliwe dzięki analizie artykułów zamieszczonych na łamach dziennika krakowskiego „Głos Narodu” w okresie od I lipca do 4 listopada I9I7 r. Warto tutaj podkreślić, iż autorem większości publikowanych materiałów był Franciszek Salezy Krysiak, były redaktor naczelny „Dziennika Berlińskiego”. „Głos Narodu”, wydawany w latach I893-I939 przez Katolickie Towarzystwo Wydawnicze, był uważany za pismo o poglądach klerykalnych i dopiero od lat trzydziestych XX w. po zmianie wydawcy stał się gazetą prorządową ${ }^{1}$. Informacje zamieszczone na łamach dziennika dotyczące sytuacji wewnętrznej związanej z przesileniami w rządzie niemieckim w omawianym okresie zaczynają pojawiać się już dużo wcześniej, niż nastąpiła pierwsza zmiana kanclerza w I9I7 r. Były to najczęściej doniesienia bezpośrednich korespondentów z Berlina, niemieckich agencji prasowych lub informacje z niemieckiej prasy, m.in.: „Alldeutsche Blätter”, „Berliner Lokal Anzeiger”, „Berliner Tageblatt”, „,Deutsche Tageszeitung”, „Germania”, „Pommersche Tagespost”, „Rheinländische Zeitung”, „Tag”, „Tägliche Rundschau”, „Vorwärts”, „Vossische Zeitung”.

Objęcie najwyższego urzędu w państwie niemieckim i zasiadanie w pięknym poradziwiłłowskim gmachu przy Wilhelmstrasse 77, służącym kanclerzom niemieckim za siedzibę, było szczytem w niemieckiej karierze urzędniczej. Sprawowanie urzędu kanclerza nie należało jednak do łatwych, wymagało bowiem od człowieka piastującego ten urząd ogromnej zręczności politycznej. Sytuacja wewnętrzna w Cesarstwie Niemieckim w połowie I9I7 r. była bardzo napięta, głównie z powodu coraz gorszej sytuacji na froncie. Zaczęto domagać się zawarcia pokoju zwanego „kompromisowym”. Dodatkowo partia Centrum dążyła do obalenia stosunkowo umiarkowanego kanclerza Theobalda von Bethmanna-Hollwega. Osoba kanclerza była również zwalczana przez konserwatywnych protestantów i narodowych liberałów, a także przez sztab generalny. Położenie kanclerza pogorszyła jego polityka w sprawie reformy prawa wyborczego w Prusach. II lipca I9I7 r. Bethmann-Hollweg nakłonił cesarza

\footnotetext{
* Markowska Anna, mgr historii na UŚ w Katowicach w 2005 r., absolwentka studiów podyplomowych z Ochrony Informacji Niejawnych i Administracji Bezpieczeństwa oraz Bezpieczeństwa Narodowego, doktorantka WNHiS UKSW, pracownik Instytutu Pamięci Narodowej w Warszawie. Dotychczasowe publikacje to dwa artykuły w monografiach poświęconych szeroko rozumianemu bezpieczeństwu narodowemu. Obszar zainteresowań to przede wszystkim dwudziestolecie międzywojenne. E-mail: markowska.anna1@wp.pl.

1 M. Jakubek, Prasa krakowska 1795-1918: bibliografia, Kraków 2004.
} 
Wilhelma II do zgody na równe prawo wyborcze. W tej sytuacji część pruskich ministrów podała się do dymisji, a dowódcy wojskowi Hindenburg i Ludendorff wystąpili do cesarza z żądaniem dokonania wyboru pomiędzy nimi a kanclerzem² ${ }^{2}$ W Berlinie słychać było głosy „Bethmann -soll-weg”, co w tłumaczeniu brzmiało „Bethmann musi iść precz”. Z początkiem lipca I9I7 r. sytuacja kanclerza była coraz trudniejsza. 9 lipca w komisji głównej parlamentu niemieckiego kanclerz oświadczył, iż nie zamierza za wszelką cenę trwać na urzędzie, ale jego ewentualna dymisja mogłaby przynieść szkodę państwu ${ }^{4}$. Io lipca odbyła się Rada Koronna, na której cesarz wraz z kanclerzem dyskutowali nad rozwiązaniem bieżących kwestii. Rozłam pomiędzy kanclerzem a większością ministrów pruskich coraz bardziej się pogłębiał. Słychać było, że pięciu ministrów pruskich i trzech sekretarzy stanu miało podać się do dymisji. Chodziło mianowicie o ministra spraw wewnętrznych Friedricha Loebella, ministra handlu Reinholda Sydowa, ministra kolei i robót publicznych Paula von Breitenbacha, ministra sprawiedliwości Maxa von Beselera i ministra oświaty Augusta von Trotta oraz o sekretarzy stanu Arthura Zimmermanna, Karla Helffericha i Wilhelma Solfa. Zmiany miał czekać także sekretariat stanu dla spraw wewnętrznych, bowiem miał on zostać zastąpiony przez ministerium robót publicznych, z oddzielnym ministerium spraw wewnętrznych, jednak znacznie ograniczonym. Na wakujące stanowiska wymieniało się posła Eugena Schiffera, jako ministra sprawiedliwości, radcę Riesera na ministra handlu oraz hr. Bernstorffa lub Wilhelma Solfa na sekretarza spraw zagranicznych. W nowych ministerstwach poseł Carl Legien miał objąć ministerstwo robót publicznych, a tekę spraw wewnętrznych obecny sekretarz stanu finansów hr. Rödern5.

Tak jak przypuszczano, sytuacja w końcu zmusiła kanclerza Bethmanna-Hollwega do rezygnacji z urzędu i przedłożenia cesarzowi prośby o dymisję. Początkowo nie było jasne, jaka będzie reakcja cesarza. Do południa I2 lipca w budynku parlamentu nie odbywały się żadne narady, bowiem czekano na decyzję cesarza w sprawie dymisji, która miała zapaść na odbywającej się tego dnia Radzie Koronnej, w której miał wziąć udział także następca tronu. Podczas Rady obradowano nad reformą wyborczą i w związku z tym oczekiwano proklamacji cesarza Wilhelma II, zawierającej powszechne, równe, tajne i bezpośrednie prawo głosowania dla Prus, oczekiwano również pewnych zmian w ministerstwie pruskim oraz częściowego sparlamentyzowania rządu Rzeszy. Pojawiły się spekulacje, że następcą Hollwega będzie ponownie ks. Bernhard von Bülow ${ }^{67}$.

I2 lipca do Berlina przyjechał bawarski szef gabinetu, hr. Georg von Hertling, który był obok ks. Bülowa - kandydatem do najwyższego urzędu. Na politykę wewnętrzną państwa duży wpływ wywierać zaczęły dążenia pokojowe w Niemczech, co było widać w wypowiedziach niektórych polityków, np. w wypowiedzi posła Matthiasa Erzbergera, członka centrum katolickiego, który swym wystąpieniem w komisji budżetowej parlamentu ostro zaatakował rząd, zażądał pokoju w drodze porozumienia i domagał się parlamentaryzacji

\footnotetext{
J. Krasuski, Historia Rzeszy Niemieckiej 1871-1945, Poznań 1969, s. 208-210.

W. Czapliński, A. Galos, W. Korta, Historia Niemiec, Wrocław 1981, s. 670.

Kanclerz o sytuacji, „Głos Narodu”, nr 162, wyd. wieczorne, 10 VII 1917.

Przesilenie w Niemczech, „Głos Narodu”, nr 163, wyd. wieczorne, 11 VII 1917.

Bülow Bernhard von (1849-1929), ks., niemiecki polityk i dyplomata, kanclerz Rzeszy i premier Prus w 1.1900-1909 .

Przesilenie w Niemczech; Przed dymisja kanclerza Rzeszy, „Głos Narodu”, nr 163, wyd. poranne, 12 VII 1917; Przesilenie w Niemczech, „Głos Narodu”, nr 164, wyd. wieczorne, 12 VII 1917.
} 
rządu. Jego krytyka odczytana została jako akt skierowany przeciwko kanclerzowi, mający na celu jego obalenie. Pojawiły się opinie, jakoby akcja posła Erzbegera doprowadziła w rządzie do przesilenia, jakiego jeszcze nie było za rządów cesarza Wilhelma II, przy czym warto dodać, że partia Centrum sama była zaskoczona wystąpieniem swego przedstawiciela, jednak mimo to udzieliła mu pełnego poparcia ${ }^{8}$.

Po kilkudniowej przerwie zebrała się komisja budżetowa parlamentu, na której jednak nie zjawił się kanclerz. Zaistniałą sytuację tłumaczył sekretarz państwa Helfferich, twierdził on, że kanclerz nie zjawił się z powodu natłoku spraw. W odpowiedzi poseł socjalistyczny Friedrich Ebert wnioskował o odroczenie terminu sesji. Komisja przychyliła się do wniosku i postanowiła odroczyć spotkanie bez podania konkretnej daty ${ }^{9}$. W kołach parlamentarnych słychać było pogłoski, że póki co, kanclerz i sekretarz pozostaną na swych stanowiskach, jedynie kilku ministrów pruskich miało zostać pozbawionych teki. Pewne było natomiast, że Helfferich i Zimmermann będą musieli odejść. Co do potencjalnych nominacji, to mówiło się o wstąpieniu jednego z przywódców związków zawodowych na urząd spraw wewnętrznych $^{\text {Io }}$. Z Berlina przeciekały informacje, jakoby stanowisko kanclerza było bardzo niepewne, głównie z tego powodu, że narodowi liberałowie i centrowcy zwrócili się przeciwko niemu. Krążyły plotki, jakoby sam prezydent amerykański Wilson nie dopuszczał możliwości zasiadania z Hollwegiem do stołu konferencyjnego. I3 lipca frakcja narodowo-liberalna parlamentu uchwaliła rezolucję, którą przesłano szefowi cywilnego gabinetu cesarza, Rudolfowi von Valentiniemu. W rezolucji napisano, że przesilenie w Niemczech nie zostanie rozwiązane dopóki Hollweg pozostanie na stanowisku, bo to w jego osobie upatruje się powód uniemożliwiający zawarcie pokoju ${ }^{\text {II }}$. Wieczorem I3 lipca niemieckie dzienniki pisały już z całą stanowczością, że prośba Bethmanna-Hollwega o dymisję zostanie przyjęta i nie ma już innej drogi do rozwiązania przesilenia. Czekano więc na nowego człowieka.

W prasie aneksjonistów, tj. „Berliner Lokal Anzeiger” oraz „Tag”, opublikowano sensacyjny artykuł, w którym pojawiła się nowa, ciekawa strona przesilenia kanclerskiego w Niemczech. Otóż autorzy tego artykułu twierdzili, że odpowiedzialność za kryzys rządowy ponosił między innymi rząd wiedeński. Chodziło mianowicie o tajemniczy telegram, który miał być rzekomo wysłany z Wiednia do Berlina, a w którym napisano, że pozostanie Hollwega na stanowisku kanclerza jest w Wiedniu wielce pożądane. Rząd wiedeński nie zgadzał się bowiem na nominację ks. Bülowa jako ewentualnego następcy na najwyższym urzędzie. Plotki donosiły, że w wysłanie tego telegramu do cesarza zamieszany był sam Bethmann-Hollweg. Ten jednak zdecydowanie zaprzeczał, jakoby próbował wpływać na decyzje w Wiedniu, chociaż pojawiały się głosy, że Hollweg pozostaje zależny od rządu wiedeńskiego. Dalej w artykule napisano, że przeciwny kandydaturze ks. Bülowa był minister spraw zagranicznych Austro-Węgier, hr. Czernin. Sytuacja była o tyle dziwna, że ks. Bülow w czasie dyplomatycznego przesilenia związanego z Bośnią stanął po stronie racji Austro-Węgier, a za problemy polityczne w Rzymie z I9I4 r. nie był odpowiedzialny nawet częściowo. To gabinet wiedeński sprzeciwiał się odstąpieniu Włochom części Trentina, co

\footnotetext{
8 Erzberger, „Głos Narodu”, nr 164, wyd. poranne, 13 VII 1917.

9 Przesilenie w Niemczech, „Głos Narodu”, nr 165, wyd. wieczorne, 13 VII 1917; Kanclerz Rzeszy „,in statu dimissionis”, „Głos Narodu”, nr 165, wyd. poranne, 14 VII 1917.

10 Bethmann-Hollweg pozostaje, „Głos Narodu”, nr 164, wyd. poranne, 13 VII 1917.

11 Dymisja kanclerza Rzeszy, „Głos Narodu”, nr 167, wyd. poranne, 17 VII 1917.
} 
radził ks. Bülow, i w wyniku tego doszło do wojny z Włochami. Tak pisał „Tag” i ostatecznie stwierdzał, że kandydatura ks. Bülowa była bardzo korzystna, bo polityk ten posiada zręczność, energię i nie raz udowodnił, że potrafi utrzymać pokój pomimo kryzysu. I tylko on jest w stanie zaradzić sytuacji, do której doprowadził kanclerz Bethmann-Hollweg. „Tag” twierdził również, że jego kandydaturę popierało całe Centrum i miałby zapewnioną większość w parlamencie. Artykuł ten przedstawiał jedną z najciekawszych zakulisowych spraw dotyczących przesilenia, bowiem pokazywał, że zwolennicy ks. Bülowa są gotowi wciągnąć w swoją politykę nawet rząd wiedeński ${ }^{\mathrm{I}}$. I4 lipca cesarz przyjął dymisję Bethmanna-Hollwega $\mathrm{z}$ funkcji kanclerza państwa, prezydenta rządu oraz ministra spraw zagranicznych i na te stanowiska powołał podsekretarza dra Georga Michaelisa. W związku z rezygnacją ze stanowisk cesarz nadał ustępującemu kanclerzowi odznaczenie gwiazdy wielkiego komtura królewskiego orderu Hohenzollernów i wystosował oświadczenie, że z bólem przyjął jego dymisję w tych bardzo trudnych czasach, kiedy ważą się losy państwa niemieckiego ${ }^{\mathrm{I}}$.

Przy okazji dymisji Bethmanna-Hollwega warto przypomnieć, że jego obecność na stanowisku kanclerskim - po zdecydowanie antypolskim ks. Bülowie - spowodowała, że zelżała polityka Niemiec wobec Polaków, jednak na przeprowadzenie zasadniczej zmiany zabrakło byłemu kanclerzowi zarówno odwagi jak i inicjatywy. Z pozytywnych zmian można wymienić: usunięcie siedmiu ministrów szczególnie niechętnych Polakom, tj. m.in. Georga Rheinbabena, Bernharda Arnima czy naczelnego prezesa Księstwa Wilhelma Waldowa. Hollweg zapowiedział również rewizję przedwojennej polityki wobec Polaków, ponadto zniósł paragraf językowy i mimo wielkiego sprzeciwu wniósł do sejmu pruskiego projekt zniesienia ustawy wywłaszczeniowej. W zakresie szkolnictwa wydał rozporządzenie przywracające w szkołach ludowych naukę religii w języku polskim ${ }^{14}$.

Nowo nominowany kanclerz Georg Michaelis urodził się w I857 r. w Haynau (Chojnów, pow. legnicki) na Śląsku, a w chwili wyboru miał sześćdziesiąt lat. Przed wojną był cenionym znawcą finansów w Prusach, gdzie od I879 r. był urzędnikiem. Przez kilka lat wykładał w niemieckiej szkole prawa i nauk politycznych w Tokio. Po powrocie pracował jako prokurator sądowy w Pile, a następnie w kilku zarządach miast, m.in. w Legnicy i we Wrocławiu. W I909 r. powołany został do ministerstwa finansów, gdzie pełnił funkcję podsekretarza. W czasie wojny był kierownikiem urzędu obrotem zboża, a później komisarzem żywnościowym w pruskim ministerstwie. Wybór nowego kanclerza był narzucony przez cesarza odgórnie i - jak donosiła część niemieckiej prasy - bez najmniejszego wpływu przedstawicielstwa niemieckiego. Wkrótce po objęciu stanowiska dr Michaelis rozpoczął rozmowy z przedstawicielami partii politycznych i ogłosił program nowego rządu. Oznajmił on, że chce utrzymać wewnętrzną łączność w polityce wewnętrznej5 ${ }^{15}$. Był on szóstym kanclerzem Rzeszy Niemieckiej i zarazem prezesem gabinetu pruskiego. Nazywany „homo novus", bowiem pojawił się na scenie politycznej jakby znikąd, bo ze stanowiska jednego z wielu podsekretarzy stanu. Taki skok w hierarchii urzędniczej nie był rzeczą powszechną. Co ciekawe, przed jego nazwiskiem nie było znaczącego ,von”, które często otwierało drogę do awansu politycznego. W związku z tą nominacją zaskoczenie było ogromne, bo choć

12 Bülow, Bethmann, Czernin, „Głos Narodu”, nr 166, wyd. poranne, 15 VII 1917.

13 Dymisja Bethmanna-Hollwega. Kanclerzem dr Michaelis, „Głos Narodu”, nr 166, wyd. poranne, 15 VII 1917.

14 Bethmann Hollweg a Polacy, „Głos Narodu”, nr 167, wyd. poranne, 17 VII 1917.

15 Po nominacyi kanclerza, „Głos Narodu”, nr 167, wyd. wieczorne, 16 VII 1917. 
wcześniej w spekulacjach pojawiało się jego nazwisko, to jednak nikt nie traktował tego poważnie. Co ciekawe, I3 lipca, czyli w przeddzień ogłoszenia Michaelisa kanclerzem, pojawił się artykuł w „Tägliche Rundschau”, który nie szczędził Hollwega i wprost pisał, że jedynym odpowiednim kandydatem jest podsekretarz stanu Michaelis. Według gazety był to twardy i niezłomny człowiek i - co ważne - politycznie nieobciążony, niepopierany przez żadne stronnictwo i dzięki temu wzbudzający zaufanie. Gdy następnego dnia cesarz ogłosił nominację Michaelisa, gazeta z wielką radością poparła ten wybór. „Berliner Tageblatt" ogłosił wprost, że dr Michaelis był kandydatem wielkiego przemysłu popierającego dalsze działania wojenne ${ }^{16}$. Expose nowego kanclerza zapowiedziano na I9 lipca ${ }^{17}$. Nikt nie wiedział, czego się spodziewać. Wiadomo było, że nominację jego, dokonaną bez udziału parlamentu z dużą radością powitali aneksjoniści wszechniemieccy. Ta ich radość niepokoiła inne stronnictwa, bowiem obawiały się, że Michaelis nie będzie opowiadał się za pokojem bez aneksji, a przecież większość zdawała sobie sprawę, że jest to jedyna droga do pokoju. Druga ważna sprawa, w której miał przemówić kanclerz, dotyczyła demokratyzacji Niemiec. Pewne było, że jeśli w obu tych sprawach wypowie się zgodnie z wolą większości parlamentu, to wreszcie pojawi się nadzieja dla Niemiec. Jeśli jednak postawi na dalsze trwanie wojny lub będzie mówił ogólnikami jak poprzedni kanclerz, to nic nie zmieni się w sytuacji wewnętrznej i zewnętrznej Cesarstwa Niemieckiego ${ }^{18}$.

Dr Michaelis w swoim expose oświadczył, że Niemcy nie przystąpiły do wojny, aby siłą zdobywać kraje, dlatego ani jednego dnia dłużej nie będą jej prowadzić, pod warunkiem, że zagwarantuje się im pokój honorowy. Tu cytat: ,,pragniemy przedewszystkiem zawrzeć pokój jako ci, którzy skutecznie postawili na swojem [...] Granice Rzeszy muszą być po wsze czasy zabezpieczone". W sprawie reform wewnętrznych opowiedział się za ścisłym porozumieniem pomiędzy rządem a parlamentem, tak aby na stanowiskach zasiadali ludzie mający zalety osobiste i zaufanie partii. Zapowiedział też wyraźnie, że nie da sobie wyrwać z rąk kierownictwa. Motto nowego kanclerza brzmiało ,jedność wewnątrz, zwartość na zewnątrz"ı.

Powołanie Michaelisa na stanowisko kanclerza, jak można było się spodziewać, nie spełniło oczekiwań większości stronnictw parlamentu. Oświadczenie kanclerza nie dla wszystkich było jasne, szczególnie w kwestii pokoju. Mianowicie chodziło o to, że skoro Michalis twierdził, że Niemcy nie chcą siłą zdobywać innych krajów, to jak mają zabezpieczyć granice po wsze czasy? Aneksjoniści żądali przecież wybrzeża flandryjskiego, czyli Belgii i poszerzenia granic wschodnich. Kanclerz mówił, że czeka na warunki pokoju, sam nie chce nic proponować, bo to mogłoby być odczytane jako przyznanie się do klęski militarnej. W tym samym czasie parlament uchwalił większością głosów formułę pokojową Centrum i partii postępowych. Kanclerz nie w całości się z nią zgodził, dlatego zaczęły się pojawiać kolejne niedomówienia. W kwestii polityki wewnętrznej kanclerz przyjął równe prawo wyborcze do sejmu pruskiego ${ }^{20}$.

\footnotetext{
16 Michaelis, „Głos Narodu”, nr 168, wyd. poranne, 18 VII 1917.

17 Zapowiedź expose dra Michaelisa, „Głos Narodu”, nr 167, wyd. poranne, 17 VII 1917.

18 Przed enuncyacya, ,Głos Narodu”, nr 169, wyd. poranne, 19 VII 1917.

19 Deklaracya dra Michaelisa, „Głos Narodu”, nr 170, wyd. poranne, 20 VII 1917.

20 W błędnem kole, „Głos Narodu”, wyd. poranne, 21 VII 1917.
} 
Kryzys w rządzie niemieckim nie przyniósł żadnej poprawy. Zmiana na stanowisku szefa rządu jak zawsze nie zadowoliła wszystkich. Jak widać, pomimo pokojowej rezolucji parlamentu, dla kół konserwatywnych, które wpływały zarówno na kanclerza jak i na cesarza, jasne było, że większych zmian w polityce wewnętrznej nie można było się spodziewać. W sytuacji, kiedy wybór nowego kanclerza dokonał się bez udziału partii, nie chciały one być pozbawione wpływu na politykę wewnętrzną. Tym należy tłumaczyć dwukrotne spotkanie przywódców partii z cesarzem u wicekanclerza Helffericha oraz bezpośrednią konferencję nowego kanclerza z przywódcami stronnictw.

Po 3 sierpnia, czyli po powrocie cesarza $z$ frontu, spodziewano się zmian na stanowiskach rządowych i sejmowych, m.in. ustąpienia ministra kultury i oświaty Trotta oraz ministra rolnictwa bar. Klemensa Schorlemera-Lesier. Niestety nie przewidywano zmiany na stanowisku ministra spraw wewnętrznych, którym był Loebell, pomimo, iż głosował on przeciwko równemu prawu wyborczemu do sejmu pruskiego, czym sprzeciwił się Bethmannowi-Hollwegowi. Co do dymisji ministra kolei i robót publicznych Breitenbacha sprawa nie była jeszcze przesądzona, wątpliwości nasuwała również kandydatura jego następcy bar. Schorlemera. Nie ogłoszono na razie, jakie zmiany zajdą na najwyższych stanowiskach w rządzie Rzeszy, w kuluarach mówiło się o ministrze spraw zagranicznych Zimmermannie czy o wicekanclerzu Helfferichu, którego urząd chciano podzielić na kilka mniejszych, m.in. na odrębny urząd gospodarczy Rzeszy. Ale pojawiły się głosy, że nie chodziło tylko o zmiany osobowe, ale o zmiany mentalności, bowiem - jak się okazało - zmiany na stanowisku kanclerskim na dłuższą metę nic nie dawały. Rozmowy z parlamentarzystami prowadzili już i Bülow i Bethmann-Hollweg, ale od rozmów do parlamentaryzacji rządu ciągle było daleko. Ponadto jasne było, że zmian w rządzie chciała głównie lewica i część demokratyczna partii Centrum, a zupełnie przeciwna była prawica. Co ciekawe, niejasne było stanowisko partii Centrum, szczególnie w Bawarii, gdzie doprowadzono już do parlamentaryzacji rządu. W sejmie bawarskim rządziła centrowa większość, a jej prezes Hertling był prezesem gabinetu - mimo to w sejmie Rzeszy bronił się przed rządami większości, argumentując, że parlamentaryzacja rządu Rzeszy podkopie federacyjne podstawy konstytucji. W tej sytuacji kolejne przesilenie gabinetowe nie wniosło konkretnych zmian w polityce wewnętrznej Rzeszy ${ }^{21}$. W związku $\mathrm{z}$ doniesieniami prasy o pozostaniu ministra spraw wewnętrznych na stanowisku biuro Wolffa ogłosiło informację, że II lipca minister Loebell wręczył kanclerzowi podanie o dymisję i do chwili obecnej nie wycofał $\mathrm{go}^{22} \cdot 3$ sierpnia pojawiły się doniesienia, że w przeciągu kilku dni zostanie ogłoszona lista zmian w ministerstwach w rządzie Rzeszy i rządzie pruskim: na stanowisku ministra spraw zagranicznych miał zasiąść Richard von Kühlmann, a zastępcą kanclerza miał pozostać dr Helfferich, przy czym, nie miał on obejmować dodatkowego resortu. Ministerstwo spraw wewnętrznych miało przypaść hr. Rödernowi, a nowy resort handlu miał objąć poseł Rieser. W rządzie pruskim natomiast na miejsce Trotta miał być powołany dawny sekretarz dr Schmidt, a ministerstwo spraw wewnętrznych po Loebllu objąć miał podsekretarz Drews²3.

Cesarz Wilhelm II przyjął w końcu dymisje: Beselera, Trotta, Schorlemera, Lentza i Loebella oraz sekretarzy stanu Reinholda Kraetkea, Hermanna Lisco i Arthura Zimmermanna.

21 Plon przesilenia w Niemczech, „Głos Narodu”, nr 180, wyd. poranne, 1 VIII 1917.

22 Dymisya ministra Loebela, „Głos Narodu”, nr 181, wyd. wieczorne, 1 VIII 1917.

${ }^{23}$ Zmiany gabinetu w Niemczech, „Głos Narodu”, nr 183, wyd. wieczorne, 3 VIII 1917. 
Zgodził się także na ustąpienie Adolfa von Batockiego, prezydenta urzędu wojennego żywnościowego i podsekretarza stanu. Co do rezygnacji Helffericha z urzędu spraw zagranicznych cesarz nie podjął jeszcze decyzji. Poinformował jednak, że będzie stał na stanowisku, aby utrzymał on zastępstwo kanclerza Rzeszy i pozostał członkiem ministerstwa państwa. O wspomnianym wyżej urzędzie gospodarczym, wydzielonym ze struktur ministerstwa spraw wewnętrznych, mówiono, że ma zająć się sprawami polityki handlowej, gospodarczej i socjalnej. Na ministra spraw wewnętrznych przewidziano Maxa Wallrafa, obecnego burmistrza Kolonii, a na kierownika urzędu gospodarczego Rudolfa Schwandera. W urzędzie spraw zagranicznych funkcję sekretarza stanu miał objąć ambasador Richard von Kühlmann a kierownictwo wojennego urzędu żywnościowego Waldow. Na wakatach w ministerstwie pruskim zasiąść mieli: Peter Spahn, jako minister sprawiedliwości, Wilhelm Drews, jako minister spraw wewnętrznych, Schmidt - minister wyznań, Eisenhart- Rothe - minister rolnictwa i Hergt, jako minister skarbu i prezydent rządu².

Zmiany w rządzie nie zadowoliły niemieckiej prasy liberalnej, uważano, że są one zupełnie bez znaczenia dla obecnej sytuacji w Niemczech. Zarzucano jednocześnie kanclerzowi pozostawienie w rządzie Helffericha jako przedstawiciela dawnego systemu ${ }^{25}$. Znaczących zmian po wielkim przesileniu parlamentarnym i kanclerskim w Niemczech nikt już nie oczekiwał. Dramatycznie rozpoczęte przesilenie do punktu kulminacyjnego doszło po przeforsowaniu przez Bethmanna-Hollwega równego prawa wyborczego do sejmu pruskiego. Pomimo zwycięstwa kanclerza doszło jednak do jego upadku oraz powołania następcy, o którym niewielu wcześniej słyszało. Zmiany miały być ogłoszone na początku sierpnia, i tak też się stało. Spektakularnej parlamentaryzacji jednak nie było, bowiem do rządu zarówno Rzeszy jak i Prus powołano zaledwie po jednym przedstawicielu parlamentu, a reszta powołanych urzędników była mało znana i dotychczas w polityce nie brała czynnego udziału. Warto dodać, że powołany minister Spahn miał już 72 lata i świeżego powiewu nikt się po nim nie spodziewał. Poza tym wybór nowych ministrów, których powołał kanclerz, nie zapowiadał nowej polityki ani wzmocnienia wpływu parlamentu na rząd. Rezultat przesilenia można było ująć przysłowiem ,z wielkiej chmury mały deszcz"26.

Już w drugiej połowie sierpnia 1917 r. pojawiły się pogłoski o rzekomym nowym przesileniu w rządzie. Miało ono wynikać z przekonania, jakoby kanclerz bez zgody większości stronnictw złożył oświadczenie dotyczące polityki państwowej. Wraz z rozpoczęciem obrad parlamentu po wakacyjnej przerwie pojawiły się nowe dyskusje na temat kanclerza i jego programu. Coraz częściej słychać było, że zmiana kadr w rządzie nie wniosła nic nowego. Rząd Michaelisa nie miał żadnego kierunku i działał półśrodkami, aby nie zrazić do siebie żadnej ze stron. Partia socjalistyczna była przeciwna systemowi, któremu zawdzięczał swą działalność rząd, a to dlatego że przy jego tworzeniu nikt nie pytał parlamentu. Według przedstawicieli partii kanclerz nie określił swoich intencji i nie uznał, że jego praca musi być ściśle związana z parlamentem. Mówiono głośno, że będzie mógł trwać na stanowisku tylko wówczas, jeśli będzie posiadał zaufanie parlamentu, a dopóki jasno nie określi swojego stanowiska, dopóty groźba przesilenia będzie wisiała w powietrzu. Partia Centrum, postępowa partia ludowa, a także narodowi liberałowie chcieli parlamentaryzacji rządu

24 Dymisye ministrów pruskich, „Głos Narodu”, nr 185, wyd. wieczorne, 6 VIII 1917.

25 Po nominacyach ministrów w Niemczech, „Głos Narodu”, nr 186, wyd. wieczorne, 7 VIII 1917.

${ }_{26}$ Zmiana osób nie systemu, „Głos Narodu”, nr 186, wyd. poranne, 8 VIII 1917. 
i grozili wprost, że jeśli kanclerz nie zgodzi się z tymi żądaniami, to przesilenie wystąpi w ostrzejszej formie niż poprzednio. Co do obecności parlamentarzystów w rządzie, tj. posła Spahna i Schiffera, to widoczne było, że od kiedy złożyli oni swe mandaty, stracili kontakt $\mathrm{z}$ własnymi partiami ${ }^{27}$.

23 sierpnia na posiedzeniu parlamentu niemieckiego kanclerz wypowiedział się co do stanowiska Niemiec $\mathrm{w}$ sprawie pokoju ${ }^{28}$. Stanowisko to, pozostając $\mathrm{w}$ sprzeczności z formułą pokoju uchwaloną przez parlament, doprowadzić musiało do oziębienia stosunków pomiędzy kanclerzem a większością stronnictw. Chodziło tu głównie o stwierdzenie kanclerza, że przyjmuje rezolucję, ale tak, ,jak on ją pojmuje”. Prasa niemiecka od razu ostro skrytykowała wypowiedź Michaelisa, uważając ją za polityczny błąd i żądając pociągnięcia go do odpowiedzialności za te słowa. Odmienne stanowisko zajęła niemiecka prasa socjalistyczna, przyjmując, że takie zachowanie tworzy rozłam pomiędzy kanclerzem a większością parlamentarną, a sam kanclerz nie zajął konkretnego stanowiska ${ }^{29}$. W obecnej sytuacji partie większościowe za pośrednictwem posła Friedricha von Payera postawiły kanclerzowi formalne ultimatum, aby bez zastrzeżeń poparł rezolucję większości. Mimo, iż obiecał to uczynić, partie większościowe uchwaliły rezolucję przeciw kanclerzowi i tylko pośrednictwo posła Payera pozwoliło uspokoić napiętą sytuację ${ }^{30}$.

Na początku sierpnia papież Benedykt XV wystąpił z pośrednictwem i wystosował do Niemiec depeszę w sprawie pokoju, w której sugerował przywrócenie granic przedwojennych, ale nie wykluczał ,rozsądnego kompromisu” "3. W odpowiedzi wydana została nota i była ona o tyle ważna, że już nie chodziło tylko o kwestie pokoju, ale również i o sprawy wewnętrzne w polityce niemieckiej. Niemcy powołali się na uchwaloną „rezolucję pokojową" z I9 lipca. Większość sejmu czekała na ruch ze strony kanclerza, w którym określi on, czy będzie umiał współpracować, czy zdecyduje się na otwartą wojnę, bo przecież, pomimo przedyskutowania sprawy w komisji pięciu, jej decyzja nie była dla kanclerza wiążąca. Tak więc nota niemiecka stała się próbą sił pomiędzy większością sejmu a losem kanclerza ${ }^{32}$.

$Z$ początkiem września pojawiły się nowe informacje o rzekomych planach rozwiązania sejmu Rzeszy wysuwanych przez partię wszechniemiecką, konserwatystów i wielkich fabrykantów ${ }^{33} .27$ września w komisji głównej sejmu Rzeszy przemawiał kanclerz Michaelis. W związku z jego wypowiedzią prasa prawicowa nie kryła zadowolenia, uważano, że kanclerz mówił jasno i wyraźnie i dał do zrozumienia, że polityka niemiecka pozostanie bez zmian. Inaczej wypowiedź kanclerza interpretowała prasa lewicowa, m.in. „Vorwärts”, twierdząc, że kanclerskie „,na razie” nie zamyka drogi rokowań34.

Kolejnym problemem politycznym dla kanclerza Michaelisa stała się sprawa agitacji w wojsku. W sejmie Rzeszy odbyła się burzliwa dyskusja nad interpelacją w tej sprawie. Doszło do gwałtownych protestów po wystąpieniu posła Landsberga, a następnie po

\footnotetext{
27 Przesilenie kanclerskie?; Socjaliści przeciw kanclerzowi; Nowe chmury, „Głos Narodu”, nr 198, wyd. wieczorne, 22 VIII 1917.

28 Polityczna debata parlamentu niemieckiego, „Głos Narodu”, nr 199, wyd. poranne, 24 VIII 1917.

29 Kanclerz a partye, „Głos Narodu”, nr 200, wyd. wieczorne, 24 VIII 1917.

30 Ultimatum pod adresem kanclerza, „Głos Narodu”, nr 200, wyd. wieczorne, 24 VIII 1917.

31 J. Krasuski, Historia Rzeszy Niemieckiej 1871-1945, Poznań 1969, s. 209.

32 Odpowiedź na notę papieża a kanclerz, „Głos Narodu”, nr 220, wyd. wieczorne, 18 IX 1917.

33 Rozwiazanie sejmu Rzeszy?, „Głos Narodu”, nr 209, wyd. wieczorne, 4 IX 1917.

34 Po mowie kanclerza, „Głos Narodu”, nr 231, wyd. poranne, 2 X 1917.
} 
wypowiedzi ministra wojny gen. Steina. Na posiedzeniu nie było kanclerza, a w jego zastępstwie chciał zabrać głos dr Helfferich, którego posłowie nie dopuścili do słowa, krzycząc: „Nie, nie, nie mamy do Pana zaufania!”. Następnego dnia odbyła się dwugodzinna narada stronnictw nad zaistniałą w sejmie sytuacją ${ }^{35}$. Kanclerz na kolejnym posiedzeniu komisji głównej sejmu Rzeszy stanowczo protestował przeciwko takiemu zachowaniu. Powiedział wprost, że podlegli mu urzędnicy państwowi mają wolność przekonań politycznych, ale powinni pamiętać, że w wystąpieniach poza partią muszą zachować rezerwę. Kanclerz nie opowiedział się bezpośrednio przeciwko agitacji w wojsku, co nie zadowoliło części posłów i zaczęły pojawiać się żądania, aby szef rządu bezwarunkowo zakazał takiego zachowania ${ }^{36}$. Na krótki czas udało się uspokoić zamieszanie wywołane dyskusją nad agitacją polityczną i nieudanym wystąpieniem Helffericha w sejmie Rzeszy. Stronnictwa większościowe nie chciały doprowadzić do dymisji Michaelisa i odrzuciły wniosek socjalistów w sprawie votum nieufności wobec kanclerza i rządu. Jednak było już pewne, że ofiarą przesilenia padnie wicekanclerz Helfferich, nazywany przez większość „,ersatzem ${ }^{37}$ kanclerskim”, który ,jest mężem stanu dopóki milczy”38. Jednak problem agitacji w armii wkrótce powrócił. 9 października kanclerz, chcąc osłabić zarzuty, jakoby rząd popiera i prowadzi agitację przeciw pokojowi, polecił sekretarzowi marynarki, Eduardowi von Capelle, aby przedstawił rzekome zarzuty wobec trzech posłów partii socjalistycznej: Wilhelma Dittmana, Hugo Haasego i Ewalda Vogtherra. Chodziło mianowicie o prowadzenie agitacji wśród marynarzy w porcie Wilhelmshaven nad Morzem Północnym. Ruch kanclerza nie spodobał się jednak pozostałym partiom, które stanęły murem w obronie socjalistów, twierdząc, że nie przystoi przedstawicielowi rządu burzyć jedności niemieckiej. Cały ten zamęt wynikał z różnic zapatrywania się na potencjalny pokój39.

Zajścia w parlamencie niemieckim z 9 października uważano za klęskę rządu i co gorsza kompromitację Rzeszy. Większość parlamentarna uważała, że oskarżenia wobec partii socjalistycznej były nadużyciem, a materiały przedstawione przez ministra Capellego ograniczały się tylko do zeznań dwóch marynarzy, którzy - jak twierdził kanclerz - zostali już rozstrzelani. Co ważne, nie chodziło tu o żadne wielkie rewolucyjne sprzysiężenie, lecz o zwyczajny wypadek oporu wojskowego, a na udział w nim posłów socjalistycznych nie przedstawiono żadnych dowodów. Ponadto swymi wypowiedziami Michaelis i Capelli podsycili nadzieję, że w Niemczech istnieje realna szansa na działalność bolszewicką ${ }^{40}$. Oskarżeni posłowie zażądali powołania parlamentarnej komisji śledczej w celu wyjaśnienia oskarżeńn ${ }^{41}$. Sytuacja wewnętrzna zaczynała być coraz bardziej napięta i coraz częściej słychać było głosy sugerujące kanclerzowi, aby dla dobra interesu kraju ustąpił ze stanowiska ${ }^{42}$.

\footnotetext{
35 Sejm Rzeszy przeciw rzadowi; Sytuacja w parlamencie niemieckim, „Głos Narodu”, nr 237, wyd. wieczorne, 8 X 1917 [szerzej: Dwie wole, Głos Narodu, nr 237, wyd. poranne, 9 X 1917].

36 Kanclerz Rzeszy o agitacyi politycznej; Uchwały partyi większości, „Głos Narodu”, nr 237, wyd. poranne, 9 X 1917.

37 Der Ersatz z niemieckiego oznacza 'substytut', 'namiastkę', 'towar zastępczy'.

38 Dr. Helfferich in statu dimissionis, „Głos Narodu”, nr 238, wyd. wieczorne, 9 X 1917.

39 Najlepsza parada, „Głos Narodu”, nr 239, wyd. poranne, 11 X 1917.

40 Michaelis musi pójść!; Fałszywy krok rządu, „Głos Narodu”, nr 240, wyd. wieczorne, 11 X 1917.

41 Oskarżeni posłowie żądaja śledztwa; Stanowisko prokuratorii, „Głos Narodu”, nr 240, wyd. wieczorne, 11 X 1917.

42 Zamiary większości, „Głos Narodu”, nr 240, wyd. wieczorne, 11 X 1917.
} 
Partia wszechniemiecka, która była odpowiedzialna za upadek kanclerza Bethmanna-Hollwega, podejmowała próby skłonienia Michaelisa do popierania jej polityki. Kanclerz jednak, mimo iż wywodził się z ich środowiska, postępował bardzo ostrożnie, nie chcąc zrazić zarówno skrajnej prawicy jak i reszty parlamentu. Często nie zabierał głosu sam, ale zlecał to swemu zastępcy Helfferichowi i ministrowi wojny Steinowi, jednak ich wypowiedzi nie uspakajały opinii publicznej. Przedstawiciele partii, którzy wcześniej uważali Michaelisa za osobę, której warto zaufać i liczyli, że uda się mu poprowadzić politykę odmienną od proponowanej przez większość parlamentarną, teraz zauważyli, że zabrakło mu energii, a jego zdolności dyplomatyczne całkowicie zawiodłył3. Stało się jasne, że kanclerz poniesie klęskę, jeśli pozwoli sobą manipulować, szczególnie, że partia wszechniemiecka wołała już głośno do cesarza o konieczność nadejścia zbawcy44.

II października poinformowano, iż należy spodziewać się oświadczenia kanclerza, że oskarżenia Capellego przeciwko posłom socjalistycznym nie były uzasadnione i że kanclerz nie chciał, aby podane zostały do wiadomości publicznej w tej formie. Kolejnym spodziewanym ruchem byłaby dymisja zarówno Capellego jak i wicekanclerza Helffericha. Rozważane były również zmiany na stanowisku kanclerza, gdzie Michaelisa miałby zastąpić gen. Wilhelm von Groener, którego partie większościowe uważały za człowieka odpowiedniego do przeprowadzenia reform w rządzie ${ }^{45}$. Jednak obrady stronnictw większości z II października nie doprowadziły do żadnych uchwał. Mimo to stało się jasne, że Michaelis nie może pozostać na swym stanowisku, a dymisja Capellego byłaby najlepszym rozwiązaniem. Dni Helffericha także były już policzone. Kanclerz przyjął u siebie przedstawiciela partii większościowych, posła Payera, który przedstawił oczekiwania na rozwiązanie obecnego przesilenia ${ }^{46}$. Jednak wszyscy zdawali sobie sprawę, że przesilenie zostanie rozwiązane dopiero po powrocie cesarza z frontu. Póki co ani Capelli, ani Michaelis nie mieli zamiaru podawać się do dymisji. W sprawie wyjaśnienia oskarżeń wobec posłów socjalistycznych komisja złożona z siedmiu przywódców stronnictw i siedmiu członków Rady Związkowej po zbadaniu materiałów przedłożonych przez dra Michaelisa oświadczyła, że podstaw do postępowania karnego nie było ${ }^{47}$. Po tym oświadczeniu podsekretarz państwa urzędu marynarki Capelle wręczył prośbę o dymisję. Natychmiast pojawiły się spekulacje, że również minister wojny i wicekanclerz marynarki złożą podanie o zdjęcie z urzędów ${ }^{48}$.

Sytuacja kanclerza stawała się coraz trudniejsza, zaufania większości parlamentu nie posiadał, lawirował pomiędzy wszechniemczyzną a pokojowo nastawioną większością sejmu Rzeszy. Dymisja ministra Capellego nie zadowalała większości parlamentarnej, bowiem oskarżenia wobec posłów socjalistycznych nie były przecież jego samodzielnym pomysłem, a winny temu był przede wszystkim sam kanclerz, bo to on odpowiadał za swych urzędników i to on powinien ponieść konsekwencje. Pojawiły się żądania jego bezwarunkowego ustąpienia ${ }^{49} .23$ października pojawiła się informacja, że dymisja ministra Capellego

\footnotetext{
43 Taki̇e wszechniemcy niezadowoleni, „Głos Narodu”, nr 240, wyd. wieczorne, 11 X 1917.

44 Wszechniemcy, „Głos Narodu”, nr 239, wyd. wieczorne, 10 X 1917.

45 Groener kandydatem na kanclerza, „Głos Narodu”, nr 241, wyd. wieczorne, 12 X 1917.

46 Dymisja Capellego-jedynym wyjściem, „Głos Narodu”, nr 241, wyd. wieczorne, 12 X 1917.

47 Kryzys w Niemczech, „Głos Narodu”, nr 242, wyd. wieczorne, 13 X 1917.

48 Dymisja podsekretarza Capellego, „Głos Narodu”, nr 242, wyd. poranne, 14 X 1917.

49 Von Capelle, „Głos Narodu”, nr 243, wyd. poranne, 15 X 1917.
} 
nie została przyjęta i w związku z tym należało się spodziewać zmiany na stanowisku kanclerza i wicekanclerza ${ }^{50}$. Jednak obawiano się powtórzenia sytuacji, która zaistniała po odwołaniu Bethmana-Hollwega, a mianowicie decyzji cesarza bez porozumienia z parlamentem, dlatego zaczęto głośno wołać o porozumienie pomiędzy cesarzem a większością parlamentarną w sprawie ewentualnego powołania nowego kanclerza. Koniec obecnego przesilenia spodziewany był jednak dopiero po powrocie cesarza i nie było już wątpliwości, że Michaelis sam ustąpi z urzędu. Sprawa zdawała się być już do tego stopnia przesądzona, że głośno mówiono o kandydatach na jego następcę. Wymieniano nazwiska byłego kanclerza, ks. Bülowa, sekretarza skarbu państwowego hr. Röderna i sekretarza stanu ministerstwa spraw zagranicznych dra Kühlmanna oraz posła w Norwegii Hinzego ${ }^{51} .22$ października wieczorem wrócił do Berlina cesarz Wilhelm II, wcześniej jeszcze w pociągu wysłuchał sprawozdania szefa gabinetu marynarki, a następnego dnia rano sprawozdania sztabu generalnego ${ }^{52}$. W następnych dniach miała się odbyć konferencja cesarza z przywódcami partii parlamentarnych, na której miało dojść do wyjaśnienia obecnej sytuacji wewnętrznej53.

W Niemczech sprawa permanentnego przesilenia nazywana już była „Eine latente Krisis nieustające przesilenie”. Stało się tak głównie dlatego, że w ciągu trzech miesięcy rządów kanclerza Michaelisa były już trzy przesilenia, w ciągu tego okresu Michaelis wygłosił niezliczoną ilość mów, więcej niż jego poprzednik przez trzy lata, jednak żadna z nich nie wyjaśniła sytuacji wewnętrznej. Kanclerstwo Michaelisa było zupełną improwizacją, a jego dni były policzone. Po nieudanym ataku na partię socjalistów kanclerz był w bardzo trudnym położeniu. Podczas rozmowy z przedstawicielami posłów partii większościowych, Trimbornem, Payerem i Ebertem, gotów był nawet poświęcić swego zastępcę Helffericha i jego stanowisko zaproponował Payerowi, który jednak odmówił, przyjął je dopiero w rządzie kolejnego kanclerza, hr. Hertlinga ${ }^{54}$. Tymczasem Michaelis był zdania, że nie widzi potrzeby zmiany na stanowisku szefa rządu ${ }^{55}$. Jednak z Berlina coraz częściej słychać było głosy o mającej nastąpić w nadchodzących dniach dymisji kanclerza ${ }^{56}$. 29 października wieczorem w niektórych niemieckich dziennikach pojawiła się informacja o rzekomej prośbie o dymisję z 28 października złożonej cesarzowi przez kanclerza Michaelisa ${ }^{57}$. Było to o tyle prawdopodobne, że cesarz przyjął tego dnia bawarskiego prezydenta ministrów, hr. Hertlinga. Jak się później okazało, na spotkaniu zaproponował mu objęcie stanowiska kanclerza Rzeszy. Hr. Hertling obiecał rozważyć propozycję, jednak wcześniej chciał odbyć rozmowy z przywódcami stronnictw większościowych. Na audiencję do cesarza oprócz Hertlinga został również zaproszony Michelis, którego dymisja została przyjęta ${ }^{5}$. Jak wiadomo, hr. Hertling wahał się przed objęciem stanowiska, bowiem nie chciał zgodzić się na rozdział stanowiska kanclerza Rzeszy od stanowiska pruskiego prezydenta ministrów.

\footnotetext{
Ogólne przesilenie rządowe w Niemczech?, „Głos Narodu”, nr 249, wyd. poranne, 23 X 1917.

Przesilenie kanclerskie w Niemczech, „Głos Narodu”, nr 250, wyd. wieczorne, 23 X 1917.

Cesarz Wilhelm w Berlinie, ,Głos Narodu”, nr 250, wyd. wieczorne, 23 X 1917.

53 Kandydaci na kanclerza, ,Głos Narodu”, nr 250, wyd. poranne, 24 X 1917.

34 Nieustajace przesilenie, „Głos Narodu”, nr 251, wyd. wieczorne, 24 X 1917.

5 Michaelis nie chce ustapić, „Głos Narodu”, nr 251, wyd. poranne, 25 X 1917.

56 Przesilenie kanclerskie w Niemczech, „Głos Narodu”, nr 253, wyd. poranne, 27 X 1917.

57 Przed dymisya dra Michaelisa, „Głos Narodu”, nr 255, wyd. wieczorne, 29 VII 1917.

58 Hr. Hertling desygnowany na kanclerza, „Głos Narodu”, nr 255, wyd. poranne, 30 X 1917.
} 
W przypadku odmowy stanowisko kanclerza miano zaproponować ponownie ks. Bülowowi ${ }^{59}$. Po potwierdzeniu, że urzędy pozostaną nierozdzielone, czego oczekiwała większa część parlamentu, było już pewne, że Hertling zdecyduje się na objęcie kanclerstwa ${ }^{60}$. I listopada cesarz przyjął go na audiencji, a ten potwierdził gotowość objęcia stanowiska ${ }^{61}$, zwrócił się też z prośbą o zwolnienie go z zajmowanej funkcji prezydenta ministrów bawarskich ${ }^{62}$. Od 30 października trwały narady w celu utworzenia nowego gabinetu, w związku z tym pojawiło się już kilka nazwisk proponowanych na ministrów, m.in. na wicekanclerza proponowano członka partii postępowej, posła Payera, a na zastępcę prezydenta ministrów, Friedberga. Szefem kancelarii państwowej miał zostać jeden z członków sejmu ${ }^{63}$. Ogłoszono także, iż żaden z socjalistycznych demokratów nie wejdzie do nowego rządu.

Zamiana następcy dra Michaelisa nastąpiła w zupełnie innej sytuacji, niż to miało miejsce w poprzednich przesileniach. Georg von Hertling, mimo iż nie był już posłem na sejm Rzeszy, został powołany dzięki rokowaniom przedstawicieli stronnictw większościowych. Stało się tak dlatego, że partie przedstawiły swoje programy kandydatowi i zgodziły się na jego powołanie dopiero po obietnicy ich wykonania. Nowy kanclerz, co ważne, na współpracowników wybrał sobie ludzi ze stronnictw, które opowiedziały się za jego nominacją, a to rodziło nadzieję, że do kolejnego przesilenia szybko nie dojdzie ${ }^{64}$.

Kanclerstwo dra Michaelisa oceniono krytycznie. Nazywany był marionetką, a jego urzędowanie - trwającym sto dni niefortunnym sprawowaniem władzy. Twierdzono, że był staropruskim biurokratą wprowadzonym na urząd przez aneksjonistów, wszechniemców, hakatystów i miłośników wojny z obozu ciężkiego przemysłu, którzy podsunęli go cesarzowi, aby za jego pośrednictwem rządzić i rozbić od wewnątrz większość pokojową parlamentu, a także sparaliżować reformę sejmu pruskiego. Niestety przeliczyli się. Michaelis, zostawszy kanclerzem, zawiódł ich oczekiwania. Nie był mentalnie przygotowany do rządzenia, nie umiał pogodzić żądań prawicy i lewicy. W końcu musiał ustąpić na żądanie czterech wielkich stronnictw po niefortunnym ataku na socjalistów i aferze po wystąpieniu szefa marynarki. Zakończenie obecnego przesilenia odbyło się nietypowo, inaczej niż przy poprzednich takich sytuacjach. Tym razem odbyło się ono przy pełnej świadomości i przy współdziałaniu partii parlamentarnych. Pozwoliło to uniknąć sytuacji, w której nominacja kanclerza byłaby niespodzianką. Teraz monarcha uzgodnił wybór następcy Michaelisa ze stronnictwami parlamentarnymi i nowym kanclerzem uczynił hr. Hertlinga, który miał olbrzymie doświadczenie parlamentarne (od 5 lat był prezesem rządu bawarskiego, a od 37 lat sprawował mandat posła parlamentu niemieckiego). Cesarz zdawał sobie sprawę z tego, że najlepszym kandydatem będzie człowiek mający zaplecze polityczne w partii, która stanowiła większość w parlamencie, mianowicie partii Centrum, zrzeszającej niemieckich katolików ${ }^{65}$.

Ponad cztery miesiące nieustannych napięć w niemieckiej polityce wewnętrznej pokazały, jak trudna była sytuacja w Cesarstwie Niemieckim, w którym plon zbierała I wojna

59 Przesilenie kanclerskie, „Głos Narodu”, nr 256, wyd. wieczorne, 30 X 1917; Rokowania hr. Hertlinga ze stronnictwami, „Głos Narodu”, nr 256, wyd. poranne, 31 X 1917.

${ }^{60}$ Hr. Hertling kanclerzem, „Głos Narodu”, nr 257, wyd. poranne, 1 XI 1917.

${ }^{61}$ Hr. Hertling kanclerzem, „Głos Narodu”, nr 258, wyd. wieczorne, 2 XI 1917.

62 Nowy gabinet niemiecki, Głos Narodu", nr 258, wyd. wieczorne, 2 XI 1917.

${ }^{63}$ Hr. Hertling kanclerzem Rzeszy, „Głos Narodu”, nr 258, wyd. poranne, 3 XI 1917.

${ }^{64}$ System parlamentarny w Niemczech, „Głos Narodu”, nr 259, wyd. wieczorne, 3 XI 1917.

65 Przesilenie rozwiazane, „Głos Narodu”, nr 259, wyd. poranne, 4 XI 1917. 
światowa, jakie zmiany wzbierały w niemieckim społeczeństwie i jak bardzo Niemcy musiały zmienić mentalność agresora. Te wahania poglądów różnych partii politycznych w parlamencie i sejmie pruskim były odzwierciedleniem nastrojów, jakie w nich panowały.

Sprawy niemieckie były ważne również dla Polaków, gdyż rok I9I7 i sytuacja na frontach I wojny światowej rodziły coraz większe nadzieje na całkowite odzyskanie niepodległości. Było to powodem dużego zainteresowania zachodnim sąsiadem i bogactwa informacji w doniesieniach prasowych na ten temat. Dzięki temu można dziś dokładniej przyjrzeć się różnym zakulisowym rozgrywkom w polityce wewnętrznej Cesarstwa Niemieckiego.

\section{The crises of the chancellor's position in the German Empire in 1917 in the account of the Krakow newspaper "Glos Narodu"} Abstract

The article concerns governmental crises and changes in the chancellor's position that took place in the German Empire in the period between July and November I9I7. It was possible to cover this issue thanks to the analysis of articles published in the Krakow daily newspaper "Głos Narodu". This paper referred to direct correspondents from Berlin, German press agencies, or information from the German press. The author wants to show a few months of tensions in German internal politics and present various behind-the-scenes games of political parties in the government. The situation in the Empire was important for us, Poles, because the year I9I7 and the reports from the fronts of World War I gave rise to more and more hopes for regaining independence.

Keywords: German Empire, German Chancellors, government crisis, World War I, I9I7

\section{BIBLIOGRAFIA}

\section{Publikacje}

Czapliński W., Galos A., Korta W., Historia Niemiec, Wrocław I98I.

Jakubek M., Prasa krakowska I795-I9I8: bibliografia, Kraków 2004.

Krasuski J., Historia Rzeszy Niemieckiej I87I-I945, Poznań I969.

\section{Prasa}

„Głos Narodu" numery:

I62, wyd. wieczorne, Io VII I9I7.

I63, wyd. wieczorne, II VII I9I7.

I63, wyd. poranne, I2 VII I9I7.

I64, wyd. wieczorne, I2 VII I9I7.

I64, wydanie poranne, I3 VII I9I7.

I65, wyd. wieczorne, I3 VII I9I7.

I65, wyd. poranne, I4 VII I9I7.

I66, wyd. poranne, I5 VII I9I7.

I67, wyd. wieczorne, I6 VII I9I7.

I67, wyd. poranne, I7 VII I9I7.

I68, wyd. poranne, I8 VII I9I7. 
I69, wyd. wieczorne, I8 VII I9I7.

I69, wyd. poranne, I9 VII I9I7.

I70, wyd. poranne, 20 VII I9I7.

I7I, wyd. poranne, 2I VII I9I7.

I80, wyd. poranne, I VIII I9I7.

I8I, wyd. wieczorne, I VIII I9I7.

I83, wyd. wieczorne, 3 VIII I9I7.

I85, wyd. wieczorne, 6 VIII I9I7.

I86, wyd. wieczorne, 7 VIII I9I7.

I86, wyd. poranne, 8 VIII I9I7.

I98, wyd. wieczorne, 22 VIII I9I7.

I99, wyd. poranne, 24 VIII I9I7.

200, wyd. wieczorne, 24 VIII I9I7.

209, wyd. wieczorne, 4 IX I9I7.

220, wyd. wieczorne, I8 IX I9I7.

23I, wyd. poranne, 2 X I9I7.

237, wyd. wieczorne, 8 X I9I7.

237, wyd. poranne, 9 X I9I7.

238, wyd. wieczorne, 9 X I9I7.

239, wyd. wieczorne, Io X I9I7.

239, wyd. poranne, II X I9I7.

240, wyd. wieczorne, II X I9I7.

24I, wyd. wieczorne, I2 X I9I7.

242, wyd. wieczorne, I3 X I9I7.

242, wyd. poranne, I4 X I9I7.

243, wyd. poranne, I6 X I9I7.

249, wyd. poranne, 23 X I9I7.

250, wyd. wieczorne, 23 X I9I7.

250, wyd. poranne, 24 X I9I7.

25I, wyd. wieczorne, 24 X I9I7.

25I, wyd. poranne, 25 X I9I7.

253, wyd. poranne, 27 X I9I7.

255, wyd. wieczorne 29 X I9I7.

255, wyd. poranne, 30 X I9I7.

256, wyd. wieczorne, 30 X I9I7.

256, wyd. poranne, 3I X I9I7.

257, wyd. poranne, I XI I9I7.

258, wyd. wieczorne, 2 XI I9I7.

258, wyd. poranne, 3 XI I9I7.

259, wyd. wieczorne, 3 XI I9I7.

259, wyd. poranne, 4 XI I9I7. 